Article

\title{
Evaluation of Sustainability Principles in Adaptable Re-Functioning: Traditional Residences in Demirel Complex
}

\author{
Ayşegül Durukan ${ }^{1, *}$, Şebnem Ertaş Beşir ${ }^{1}$ (D) , Selver Koç Altuntaş ${ }^{2}$ (D) and Mikail Açıkel ${ }^{1}$ \\ 1 Department of Interior Architecture, Faculty of Architecture, Akdeniz University, Antalya 07070, Turkey; \\ sertasbesir@akdeniz.edu.tr (Ş.E.B.); mikailacikel@akdeniz.edu.tr (M.A.) \\ 2 Department of Interior Architecture, Faculty of Architecture, Karadeniz Technical University, Trabzon 61080, \\ Turkey; selverkoc@ktu.edu.tr \\ * Correspondence: ayseguldurukan@akdeniz.edu.tr; Tel.: +90-5513-893-909
}

Citation: Durukan, A.; Ertaş Beşir, Ş.;

Koç Altuntaş, S.; Açıkel, M.

Evaluation of Sustainability

Principles in Adaptable

Re-Functioning: Traditional

Residences in Demirel Complex.

Sustainability 2021, 13, 2514.

https://doi.org/10.3390/su13052514

Academic Editor: Vincenzo Costanzo

Received: 15 December 2020

Accepted: 17 February 2021

Published: 26 February 2021

Publisher's Note: MDPI stays neutral with regard to jurisdictional claims in published maps and institutional affiliations.

Copyright: (c) 2021 by the authors. Licensee MDPI, Basel, Switzerland. This article is an open access article distributed under the terms and conditions of the Creative Commons Attribution (CC BY) license (https:// creativecommons.org/licenses/by/ $4.0 /)$.

\begin{abstract}
Sustainable living is basically being able to construct the balance of protecting and using natural resources. In this way, the heritage value transferred to future generations is formed by the interaction of people and the environment. This is also very important for "architecture", which expresses sustainability and is an important tool. In addition to the continuity of sustainable architecture and cultural heritage, it is possible to create economic resources and detect sociological data. Local architecture, which bridges the past and the present and best reveals the relationship of people with each other and their environment, has a place in many parts of the world with its rich diversity. Local architecture has an active place in contemporary society with its cultural, socio-economic and concrete identity values. These structures are protected by various strategies and methods and transferred to future generations. One of these methods is adaptive re-use. Within the scope of adaptive re-use, the study examined the principles of sustainability through eight seconddegree registered İslamköy residences in the Demirel Complex of İslamköy village in Atabey district of Isparta province in Turkey. Thus, by evaluating three basic principles, environmental, economic and social, in terms of the continuity of local architecture with the sub-parameters determined, it was aimed to reveal the benefits and damages caused by the complex to the settlement in terms of sustainability. In this way, the change and transformation created by re-functioning with the renewal of building materials and typology was examined.
\end{abstract}

Keywords: local architecture; re-functioning; environmental sustainability; economic sustainability; social sustainability

\section{Introduction}

Sustainability is an extensive concept that includes different topics from economy to development, agriculture to environment. In 1972, it first came to the forefront with the concepts of sustainability and sustainable development at the "People and Environment" conference [1]; since then, it has found another place in different branches of science as an important issue and in state policies.

The main purpose of the concept of sustainability is to achieve the most appropriate use of resources in the long term. A sustainable life can be expressed as transferring natural resources to future generations by considering the balance of use and conservation. From the broadest point of view, sustainability is a concept transformed to a strategy from the question of how it can be adapted to world views through social, economic and political factors [2].

Sustainability, which is usually discussed in the economy, has expressed itself with "sustainable development" [3,4]. Other than that, it comes together with many issues such as sustainable agriculture, sustainable society and sustainable cities [5]. Architecture is one of the important disciplines in which sustain ability is examined and strategies and principles are determined. 
Kim and Rigdon [6] have explained concept of sustainability in the context of architecture; within the three basic categories of resource protection and re-use and recycling, life cycle and humane design. Kohler [7] defined sustainable buildings with ecological, economic, social and cultural sustainability components and stated that they are sustainable building design principles (Figure 1).

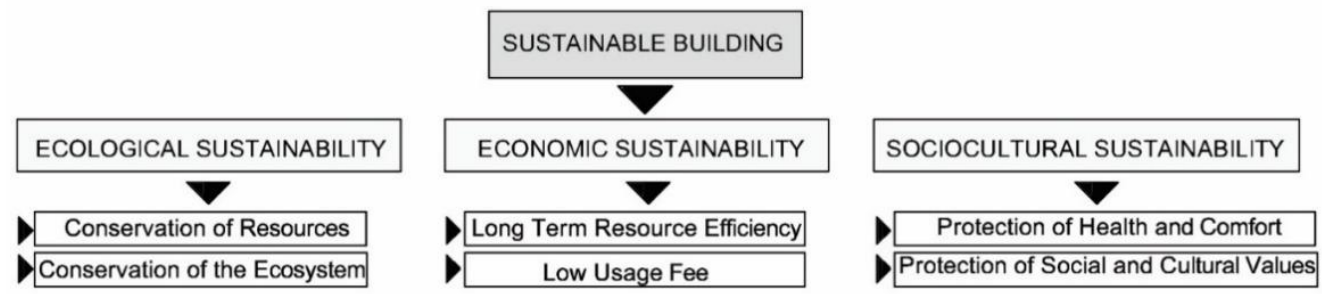

Figure 1. Sustainable building design principles [7].

Sustainable architecture has existed since the beginning of architecture and has been conceptualized and used since the 20th century. As the most general definition, it expresses environmentally sensitive structures aimed at protecting ecological resources through the interaction of man and environment [8]. Sustainable architecture is approached in its ecological, social, cultural and economic dimensions [9]. This concept, in addition to the factors mentioned achieves a holistic approach with the relationship established with location, geological structure, climate and vegetation under the title of physical environment. At this point, local architecture is the most basic example of sustainable understanding; it is shaped in the light of environmental and local data. Due to the increasing environmental challenges such as contemporary buildings, carbon footprint, uncontrollable energy consumption, wasteful use of resources, pollution, which have recently consumed the environment, researchers and practitioners have begun to recommend the sustainable character of local architecture and discuss it within the sustainable life cycle.

Numerous examples of Turkey's seven different geographical regions that make up the original texture are frequently discussed in different studies with their unique architecture. Adaptive reusing can transform heritage buildings into accessible and usable places, as well as provide the additional benefit of creating an area again in a sustainable way; when the last 30 years in Anatolia are examined, it is observed that the natural and structured environmental heritage is destroyed as a result of the constructions that have been built in violation of the region and culture, without taking into account the settlement texture in rural areas, local architectural features and the needs of local people [10]. In the studies carried out under the protection strategy in rural areas in Turkey, it can be said that deformations are experienced in terms of plan and façade, construction technique and material and decoration features. However, adaptive re-use can help communities, governments and developers in their quest to reduce the environmental, social and economic costs of continuous urban development and expansion [11-13]. Considering that rural settlements in Anatolia, which have an important inventory in terms of vernacular structure, are socio-economically deserted; adaptive re-use is expected to provide mobility to the regions. In the study, Demirel Complex, which was opened for operation in 2014, was discussed in Islamköy settlement in Isparta Province. Demirel Complex consists of the mosque, the main museum building, museum, library building, lodging and warehouse buildings. Of these buildings, eight traditional residences are used as museum house and lodging. The main museum, library and mosque structure were rebuilt in the complex. The construction complex became a new cultural and tourism area for both Islamköy and Isparta and Atabey environment, which required it to have sustainable qualities for the settlement. In this direction, by carrying out descriptive analyses of the eight structures re-functioned in Demirel Complex and making a literature review based on the elements of three main principles, it was aimed to reveal the benefits and harms of the complex to settlement in terms of environmental, economic and social sustainability for Islamköy. In this way, the continuity of the change and transformation created by re-functioning has 
been examined by renewing building materials and typology in terms of continuity of local architecture.

\section{Local Architecture in the Sustainable Life Cycle}

Local architecture still plays an active role in contemporary society, as it contains abstract and concrete identity values specific to the culture in which it is located and responds to the socio-economic and cultural character of societies. Its originality is not only related to its materiality and texture, but also to the way it is used. It is characterized by environmental adaptation in terms of local climatic conditions and topography, as well as the use of local materials with low local energy and therefore minimal environmental footprint [14].

Climatic conditions, location and geographical structure of the region determine the material possibilities of the region [15]. Materials combined with traditional methods and construction techniques are an important parameter both in terms of economy, localness and energy efficiency [16]. These materials which are termed "sustainable materials" carry renewable, recyclable, reusable properties. They also offer comfortable living opportunities for outdoor insulation and indoor air quality in addition to being sensitive to the environment and human health [17]. These features have brought with them various principles and expressions in the approach to the intervention to traditional architecture. In this context, adaptive re-use is an important protection intervention to re-transform the resources of the past and turn them into experiences in the present. The "Versus (Vernacular Heritage Sustainable Architecture)" project explored the contribution of local heritage to sustainable architecture and revealed a holistic approach. Sustainability in this project has been discussed with its environmental, socio-cultural, socio-economic dimensions; general objectives and objectives were set, and principles and strategies were developed for a more sustainable architecture in the subject of local heritage [18]. Thus, the importance of rural area and local architecture has been once again revealed. The construction of local architecture with master-apprentice relationship, providing aesthetic values with color and texture compatible with nature, keeping user requirements in the forefront, applying the principle of flexibility, finding sun radiation and insulation properties which directly coincide with sustainability concepts $[16,19,20]$.

Rural areas include a very rich diversity of structures that combine different beliefs and life habits from history, climate data in their geography and the tradition of using local building materials [17]. The continuity of this rich building culture from the past depends on many differences and is protected by new strategies and methods every day. These strategies include the protection and use of local tissue, planning its adaptation to today's conditions, and sustainable design principles [21]. Local architecture and sustainability concepts consist of two dimensions. The first is the sustainability of the renovation of building materials and typology; the second is re-functioning, sustainability of change and transformation that constitutes integration and perception and understanding of the existing building [22]. The sustainability goal requires a balance between re-use and protection. In other words, this process, which allows the re-use of a building through repairs, renovations and additions, has to focus on protecting functional solutions and materials that convey historical, cultural and community architectural values [23]. Thus, the sustainability of all local inventories can be mentioned within the life cycle.

\section{Protection of Local Architecture and Adaptable Re-Use}

Adaptive re-use includes transforming a building by taking over a change of use required by new or existing owners [24,25]. While the change of use requires partial or complete refurbishment of existing buildings or structures, adaptive re-use protects architectural, social, cultural and historical values [24]. Adaptive re-use is a process that always involves physically changing the function of a disused or ineffective building [26].

When adaptive re-use is applied to old buildings, it not only protects the building, but also preserves the efforts and skills of the original builders [13]. According to 
Bromley et al. [27], changes to buildings may include re-arrangement and replacement of the space, but they have indicated that adaptive re-use is essentially a form of heritage protection.

The practical consequences of adaptive re-use and the conceptual values of conservation support the re-use of heritage buildings as a sustainable strategy. The results of adaptive re-use include improvements in material and resource efficiency (environmental sustainability), cost reductions (economic sustainability), and retention (social sustainability) according to Cooper [28]. Accordingly, Bullen and Love [29] have become one of the main drivers of the preservation and regeneration of heritage buildings.

The local architecture is shaped according to the nature of the social and physical character of the local environment [21]. This character, which meets the common denominator, ensures its sustainability through resources that embody design and can be produced on-site and easily, together with local products obtained from the environment. In addition, it supports the principles of sustainable approach in terms of the use of renewable natural materials and energy protection in historical textures [30]. In this context, adaptive re-use of local architecture covers three areas of sustainability: environmental, economic and social principles [24,31-37] (Figure 2).

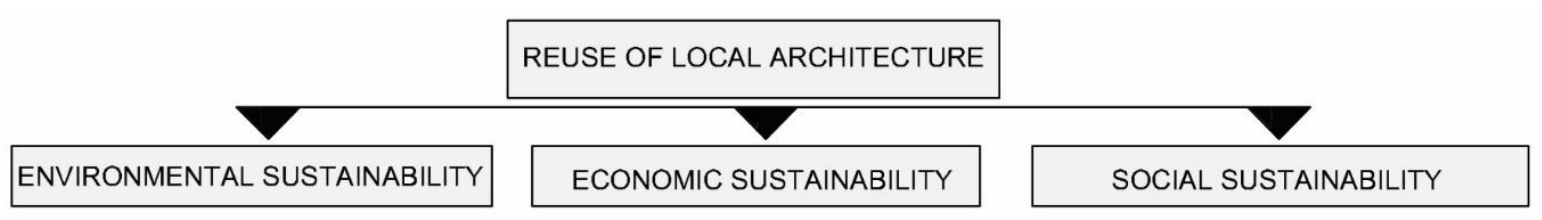

Figure 2. Architectural re-use principles.

Adaptive re-use is a strategy to protect cultural-historical values through the change and improvement of environmental, economic and social factors [38-41]. In this context, it is very important to protect the local architecture, which expresses social characteristics, with its original assets, and the level of intervention in local architecture should be carefully planned in order to contribute to the development of settlement while at the same time not to make irreversible applications.

\subsection{Environmental Sustainability in Refunctioning}

Environmental sustainability, in addition to improving human well-being and ensuring the protection of raw material resources, is a phenomenon needed by people and it emerged from the reflection of social concerns [42]. The use of local material is quite important at this stage. During the restoration process, the fact that most of the building materials in the local architecture are recycled reduces the impact on the environment. Another important point is the need for less energy due to the simple construction process. The third important point is the process of creating comfortable space with environmental performance in mind. In this context, Correia [18] emphasizes that converted or new materials used to improve the structure's resistance to environmental factors should be optimized for existing local resources.

Revitalizing architectural heritage and protecting cultural values in an environmentally conscious way requires a detailed planning process [43]. Therefore, for traditional structures within the scope of re-functioning, the use of materials that do not disturb the original texture, are easy to maintain, reusable and obtained from local sources and the construction techniques of these materials specific to that region are important. According to Yarrow [44], the preservation of traditional dwellings, an element of local architecture, places a different emphasis on the past and the future as sources of meaning and value.

Adaptive reusing transforms an area into sustainable accessible and usable locations. It becomes more meaningful when the structures are complementary to the whole and can respond to the need required in the environment in which they are located. Therefore, the location of the historical building has an important place and importance in determining 
the new function to be given to historical structures. Accordingly, natural and artificial environmental inputs in the field of architecture and re-functioning also make up the data that attract attention. Artificial environment creates important data to assess the feasibility of reusing adaptive heritage, including historic streets, surrounding attractions and high transport accessibility [45].

\subsection{Economic Sustainability in Re-Functioning}

According to Konstantinou and Dimitrijevic [46], the relevant consequences of sustainable renovation and improvement of existing buildings are also related to social factors (human needs and quality of life) and show its economic value (e.g., economic growth, job creation, etc.) Maintaining the population of a rural region and maintaining economic development is important for sustainable development [47]. Adaptive remand costs of buildings are lower than the costs of demolition and redevelopment [48] and can be created much faster than rebuilding new areas in the same settlement [49]. However, in some cases, it may be more expensive to renovate an old building to a necessary sustainable standard [50] and significant investments may be needed to renovate and maintain an old structure if there are serious structural problems or if its external structure has begun to deteriorate [11]. Choosing the materials used in buildings according to sustainability principles reduces the negative effects on natural life, as well as increasing the effectiveness of energy, reduces operating and maintenance repair costs and provides healthy, comfortable environments for the user [51].

In terms of economic sustainability, local solutions of structures aim to protect resources in order to reduce cost capacity, building performance, maintenance and increase living conditions [52]. The local material is used at this point, which is supported by local construction techniques and craftsmanship [18]. Local workforce demands are improving local crafts and trade [53].

\subsection{Social Sustainability in Refunctioning}

Sustainability is not only about environmental protection, renewable resources and building materials, but also a matter of lifestyle and cultural identity of society [43]. The well-being, identity, memory and sense of place of society in conservation are important symbols reflected in social and cultural sustainability [29]. Considering that the new function given to the structure in the changing social process may change after a while, changes in the social structure and cultural structure should be planned in advance. Therefore, those who live in the area around the structure, as well as their family structures, beliefs and political values and socio-economic situations, should be carefully evaluated. Returning structures to society as living complexes is another way to create new human environments [54].

Latham [24] stated that adaptive re-use protects architectural, social, cultural and historical values. Historical settlements and local architecture connects people to their roots, places their collective memories and reflects their cultural identity as well as their personal identity [55]. Social sustainability emphasizes the importance of diversity by addressing the way of life, spirituality, family and socio-cultural structure of societies. Sustainability for cultural and natural heritage involves meeting economic, social and aesthetic needs and includes maintaining cultural integrity and management of resources [56]. Knowing that spiritual values are a legacy and maintaining their sustainability by preserving these values, developing a common understanding among generations are also among the requirements of social sustainability [18,52]. Culturally, an important part of our heritage and identity can be preserved in this way.

\section{Methodology}

This article uses a case study approach that provides a holistic assessment of a wide range of sustainability dimensions. The impact of use by re-adapting local architecture within the lifecycle; in terms of economic, social and environmental sustainability, is 
reflected in the settlement in the short or long term. With the literature study conducted in this context, three main principles were revealed (Table 1). The descriptive analyses of the eight structures refuted in the Demirel Complex were evaluated in the context of the principles and sub-parameters determined by the literature.

Table 1. Principles and sub-parameters of sustainable living for local architecture.

Principles of Sustainable Approach in Re-Functioning
Sub-Parameters of Environmental Sustainability

\section{Sub-Parameters of Natural Environmental Features}

Local Resources, local material usage

(Correia, 2014 [18], The Scottish Office, 1999 [57], Philokyprou and Michael, 2020 [53])

Adaptation to the natural environment, characteristic environmental feature

(Koçhan, 2003 [58], Philokyprou et al. 2017 [14], Elinç et al., 2018 [59])

Ecology-sensitive, bioclimatic properties

(Koçhan, 2003 [58], Philokyprou et al. 2017 [14], Selim et al. [61])

Protection of resources

(Yarrow, 2015 [44], Carlos et al, 2014 [52], Goodland and Daly, 2019 [42])

\section{Sub-Parameters of Artificial Environmental Features}

Construction techniques

(Philokyprou and Michael, 2020 [53], Correia, 2014 [18])

Architectural appearance values, building aesthetics, architectural elements, morphological elements

(Kiper, 2004 [60], Philokyprou and Michael, 2020 [53], Carlos et al, $2014[52])$

Energy efficiency and continuity (on The Building Scale) (Philokyprou et al. 2017 [14], Yarrow, 2015 [44], Salman, 2018 [43])

Architectural layout, urban texture, planning

(Almhafdy et al., 2015 [62], Du, Bokel and van den Dobbelsteen, 2014 [63], Ghaffarianhoseini and Berardi, 2015 [64], Salman, 2018 [43])

Sub-Parameters of Economic Sustainability

Waste management

(Dennis, 2008 [65], Gökşen, Güner and Koçhan, 2017 [66],

Baysan, 2003 [67])

Reducing operating, maintenance and repair costs

(Sev, 2009 [51], Philokyprou and Michael, 2020 [53])

Energy saving, energy efficiency

(Doğan, 2019 [70], Foster and Kreinin, 2019 [71])

Management of resources regulations

(Pedersen, 2002 [56], Elsorady, 2020 [68])

Cultural activity

(Philokyprou and Michael, 2020 [53], Tu, H. M., 2020 [45], Ertaş et al., 2017 [69])

Tourism return

(Kiper, 2004 [61], Feilden, 2003 [72], Ertaş et al., 2017 [69])

Job opportunity, job creation sa

(Philokyprou and Michael, 2020 [53], Konstantinou and

Dimitrijevic, 2018 [46])

Revival of settlements, local workforce

(Philokyprou and Michael, 2020 [53], Correia, 2014 [18])

\section{Sub-Parameters of Social Sustainability}

Protection of artisanal activities

The Scottish Office 1999, [57], Philokyprou and Michael, 2020

[53]

Preservation of cultural diversity, continued

(The Scottish Office 1999, [57], Philokyprou and Michael, 2020

[53], Correia, 2014, [18], Carlos et al, 2014 [52], Bromley 2005 [27], Pedersen, 2002 [56])

Ensuring public participation in protection actions (The Scottish Office, 1999 [57], Elsorady, 2020 [68], Matero 2007 [54])

Strengthening environmental and community ties, emotional value

(Akkurt, 2010 [73], Philokyprou and Michael, 2020 [53])

Continuity of local construction and culture

(Wang and Zeng, 2010 [74], Akkurt, 2010 [73])

Balance between past and present

(Dipasquale et al., 2014 [18], Philokyprou and Michael, 2020 [53])

Existance, creation and protection of identity

(Kiper, 2004 [61], Bullen and Love, 2010 [29], Salman, 2018 [43], Watson and Bentley, 2007 [55])

Cultural function

(Philokyprou and Michael, 2020 [53], Latham, 2000 [24])

Human needs and quality of life

(Konstantinou and Dimitrijevic, 2018 [46], Philokyprou and

Michael, 2020 [53])

Memory, sense of place

(Bullen and Love, 2010 [29], Philokyprou and Michael, 2020 [53])

Human needs and quality of life

(Konstantinou and Dimitrijevic, 2018 [46], Philokyprou and Michael, 2020 [53])
Memory, sense of place

(Bullen and Love, 2010 [29], Philokyprou and Michael, 2020 [53]) 


\subsection{Field of Study (Turkey—Isparta/Islamköy)}

The study was carried out in Islamköy village of Atabey district of Isparta, located in the lakes region of Turkey (Figure 3). The history of Islamköy dates back to before the 19th century; it was home to various empires such as the Hittite, Firig, Lydia, Persian, Roman and Ottoman empires (Figure 3). While it was a neighborhood of Atabey until 1908, it was converted into a town in 1955 and finally became a village connected to Atabey due to the decrease in population [75].

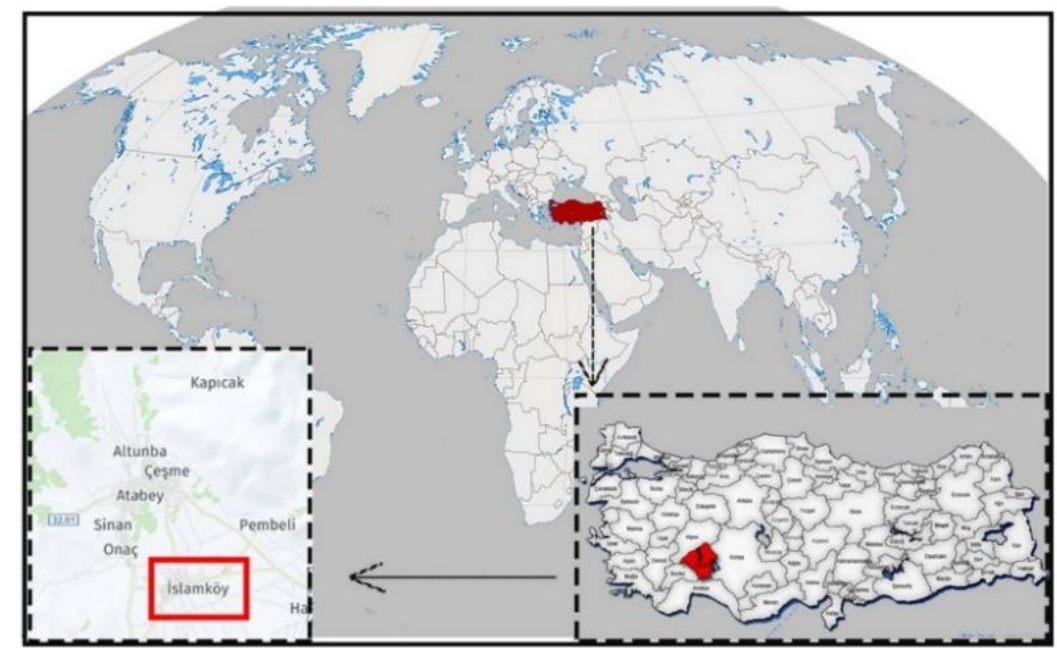

Figure 3. Location of Islamköy in Atabey district of Isparta, Turkey.

The village is located in the so-called lake district of Turkey. Due to its proximity to the Mediterranean region and its presence in the central Anatolia region, it has a transition climate. Sitting on flat land, the village has many cultivatable areas. Isparta roses, which have become the symbol of Isparta, are also found in this region. In addition, apple orchards and cultivatable vegetable gardens are seen with intensity. Their water needs are met from Eğirdir Lake. Besides livestock, an important source of income is industry. Founded in 1958, there is a rose oil factory. The existing of various workshops such as tinsmithing, sawing and iron forging are examples of variety in economic resources [75].

Islamköy village is located on the bicycle tour route. Apart from that, lavender and rose gardens are very close in location [75]. The village is located in important destination points and is suitable for sustainable cultural tourism; it is also at an important point because it is the village where Süleyman Demirel, the ninth President of the Republic of Turkey, was born and raised. Süleyman Demirel's mausoleum and the Demirel Complex draw visitors to the village every year, becoming the cultural tourism icon of the village in the process [75]. Demirel Complex in the village of Islamköy, which forms the working universe, constitutes the borders of the study.

\section{Demirel Complex}

In Demirel Complex, which is located $24 \mathrm{~km}$ away from Isparta city center and covers a large area of 17,000 square meters; there is a closed area of 6 thousand square meters. The building and restoration process of the buildings have been financed by Demirel Foundation President Cert. Engineer Şevket Demirel and his daughters Nihan Atasagun, Binhan Kesici and Neslihan Demirel; maintenance and repairs are carried out and all operation is provided. In addition, İnan Kıraç and Koç Families have transferred their knowledge and experience in private museums to the museum. A technical team formed under the chairmanship of Kayhan Dörtlük, one of the retired museum founders, contributed to the installation of the museum. In 2010-2014, this team rearranged the museum in all areas, including landscaping, and opened it in an official ceremony on 26 October 2014. Tülin Tolun, an interior designer who was one of the members of this technical team and 
responsible for the re-functioning of traditional residences, continued her duties at the museum until 6 November 2020 when she passed away. The construction started in 1990 and in the complex which opened on 26 October 2014, there are many complex buildings such as nine refunctioned residences converted into restaurants, lodgings, museum houses, guesthouses, culture-art houses, Süleyman Demirel Museum of Democracy and Development, Information and Document Center, Demirel Foundation, Şehriban Hatun Mosque, Namazgah, a fountain (Figure 4) [76,77].

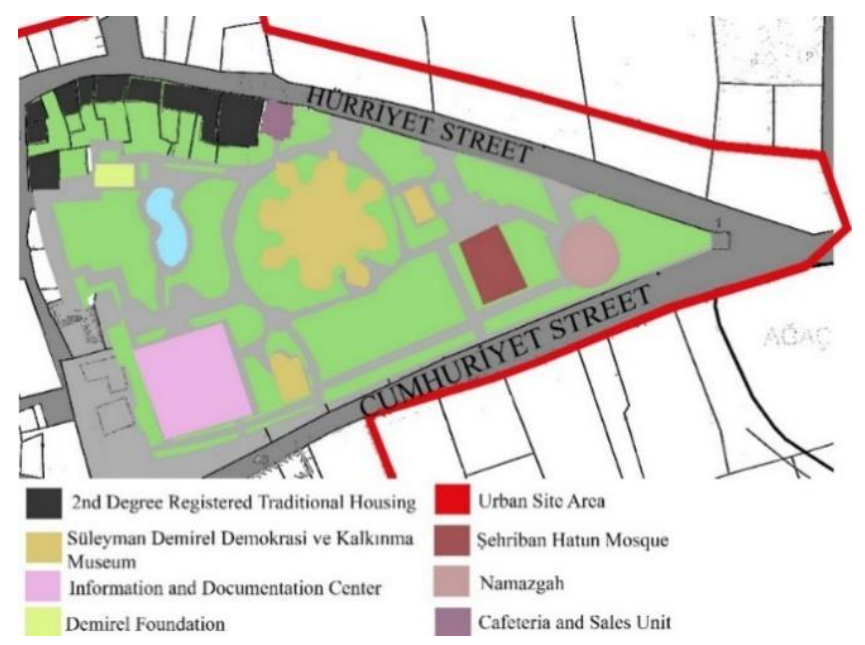

Figure 4. Demirel complex situation plan.

The complex contains information, documents, items and clothing belonging to the Demirel family and the 50-year history of the republic. The collection and exhibition of these products has created a new cultural and tourism area that can be the center of attraction for both İslamköy and Ispartasparta and Atabey (Figure 5a,b).

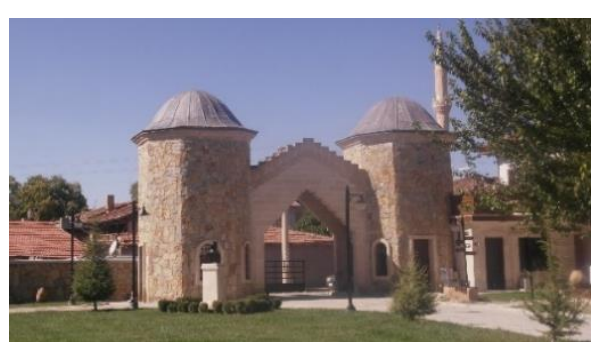

(a)

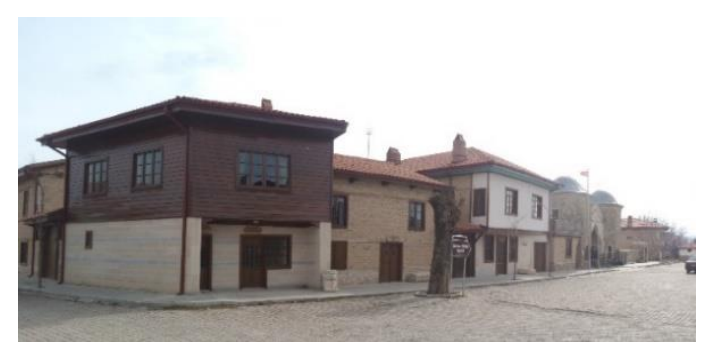

(b)

Figure 5. Demirel complex photos (a,b).

No village house included in the Demirel Complex area has been demolished, all have been restored and maintained. Within the scope of the study, the process of refunctioning these second-degree registered traditional houses was discussed; eight of the nine traditional Islamköy residences were examined and the necessary information and documents were collected (Figure 6). Thus, it is aimed to show the contribution of physical changes to environmental, economic and social sustainability. 


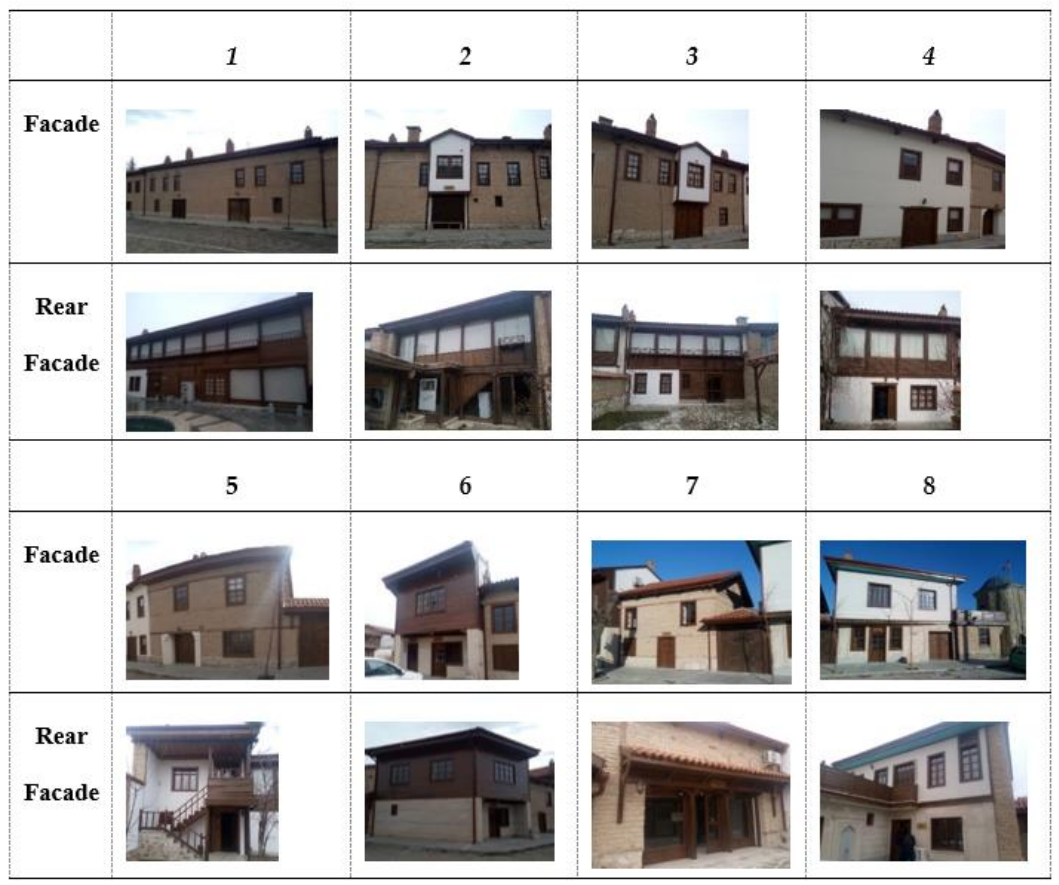

Figure 6. Eight re-functioned registered traditional houses in Demirel complex.

Accordingly, the functions given to the houses and interior are as follows (Figure 7).

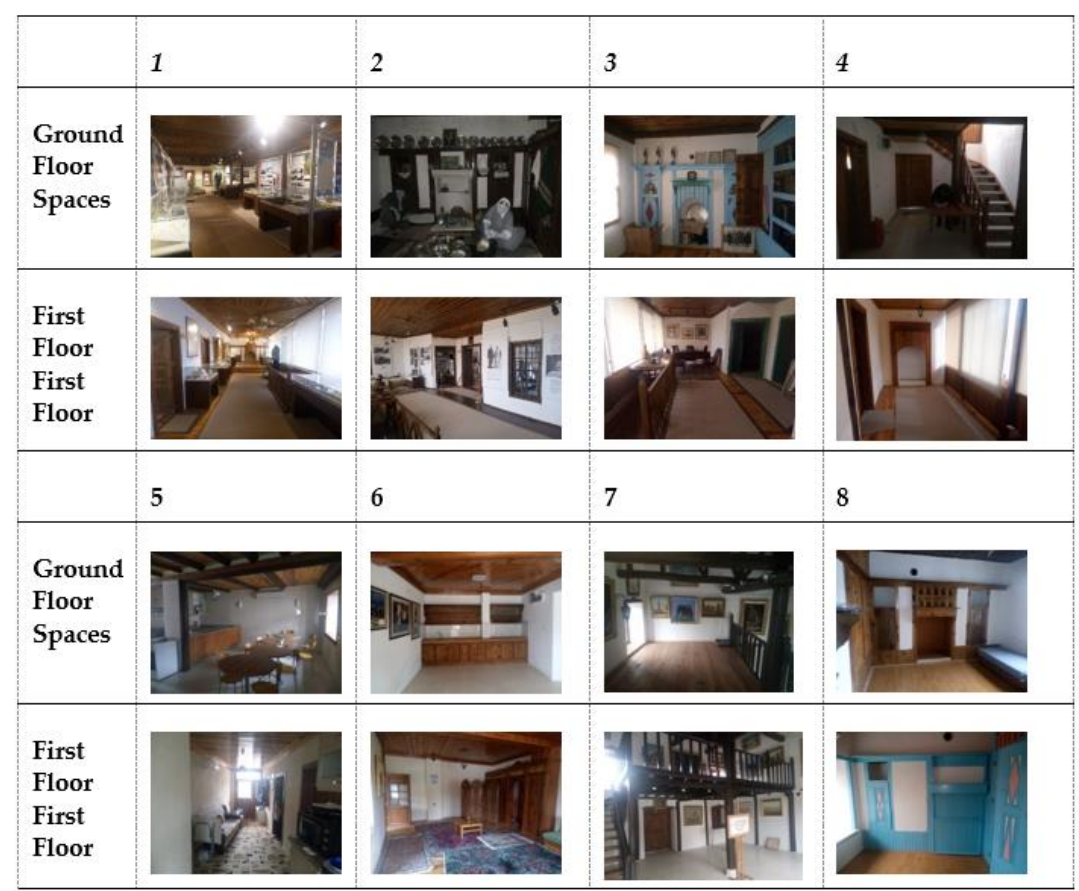

Figure 7. The interior views of eight re-functioned registered traditional houses in Demirel complex.

- The traditional residence number 1 with the two-story, four-room exterior sofa plan type was converted into Şevket Demirel Museum House.

- The traditional residence number 2 with the two-story, three-room exterior sofa plan type was converted into Demirel Museum House.

- The traditional residence number 3 with the two-story, three-room exterior sofa plan type was converted into Haci Ali Demirel House (private property). 
- The traditional residence number 4 with the two-story, two-room exterior sofa plan type was converted into a guest house.

- The traditional residence number 5 with the two-story, two-room exterior sofa plan type was converted into a lodging.

- The traditional residence number 6 with the two-story, one-room exterior sofa plan type was converted into Haci Abdil A ğa Masjid and A ğalar Kıraathanesi.

- The traditional residence number 7, with the two-story, two-room exterior sofa plan type, was converted into a Culture and Art House.

- The traditional residence number 8 with the two-story, two-room exterior sofa plan type was converted into the Presidency of the Demirel Foundation.

The houses consist of two floors, the first floor shows the character of the region. In terms of plan features, the relationship between the room and the anteroom is important. In the plan types determined according to this relationship, two typologies are found, external sofa and inner sofa. Among them, the majority are the houses with external anterooms. External anteroom plan types vary according to whether there is a suite room and the number of rooms in the mansion (Table 2).

Table 2. Plan types of eight residences.

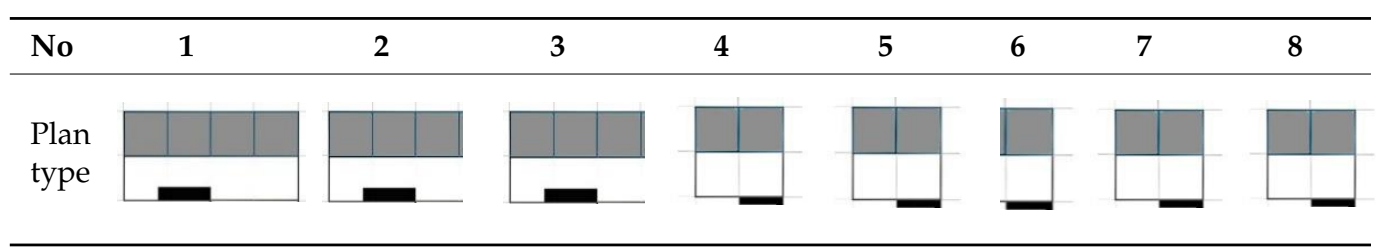

The houses consist of living and service places. Living spaces consist of groundfloor house, anteroom, room, main room, and service spaces consist of a porch, haney altı, barn, haystack and dam [78]. In the residences, the use of local materials is observed. Stone was used on the ground floor which has wooden pillar supports, on the first floor Bağdadi [78] construction technique was used and in some Hımıs [78] technique was seen. Many houses were plastered with lime. Most of the fixed and moving furnishings are wooden, mostly there are stoves, cabinets and shelves [79].

Except for traditional residences, Süleyman Demirel Museum of Democracy and Development, Information and Document Center, Demirel Foundation, Şehriban Hatun Mosque, Namazgah and the fountain were built within new buildings in the complex. The new structures were built to support the complex with functions suitable with its mission without damaging the existing texture. Among these structures, the avant-project of the Süleyman Demirel Museum of Democracy and Development belongs to the former Isparta Mayor Cert. Architect Yusuf Ziya Günaydın, and the construction project belongs to Cert. Architect Behruz Çinici. This museum is the most important building in the complex. Examples of the life and experiences of Süleyman Demirel, who served as president and prime minister in Turkey, are exhibited [79] (Figure 8a-c).

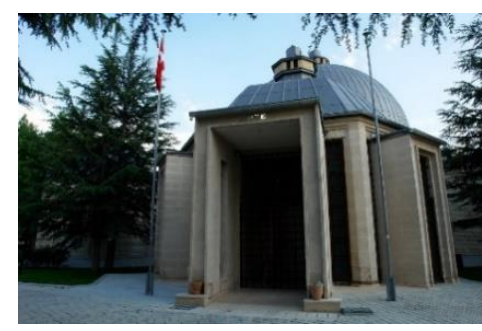

(a)

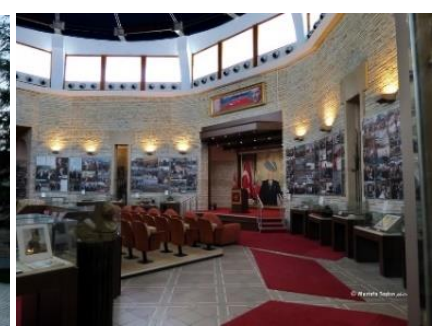

(b)

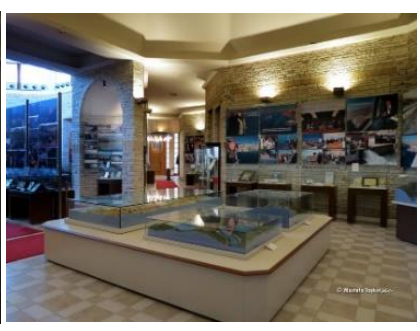

(c)

Figure 8. Süleyman Demirel Museum of Democracy and Development, (a) External View, (b) Sohwroom, (c) Meeting room [79]. 
4.2. Reviewing the Re-Functioning of Traditional Houses in Süleyman Demirel Complex According to the Principles of Sustainable Approach

\subsection{1. Şevket Demirel Museum House}

On the ground floor of Şevket Demirel Museum House there is yerden ev [78], porch and haney altı [78]. Yerden ev; is a term used for ground floor of Islamköy traditional residences. This place is located in a position where the circulation in the dwelling can be monitored and associated with the staircase that provides the connection with the first floor. The term of haney alti; is used for the space located on the ground floor and used as a supply store in traditional residences of Islamköy. These spaces and the terms of yerden ev and haney altı are characterized with the local architecture of Islamköy. The first floor of Şevket Demirel Museum House isdonated with a main room, a room and an anteroom (Table 3).

Table 3. Re-functioned Şevket Demirel Museum House [78].

\begin{tabular}{llll}
\hline \multicolumn{1}{c}{ Places } & Ground Floor Plan & First Floor Plan \\
\hline Haney Alt1 & \\
Yerden Ev \\
Porch \\
Room \\
Main Room \\
Sofa \\
Line Scale:
\end{tabular}

Through the floor plans and photos seen in the table, Yerden ev and porch spaces have been functioned as museums. On the first floor; at the enterance, rooms and sofa were evaluated with various functions such as exhibition elements, presentation room and charity room. The building, which has been converted from a residence to a museum house, provides liveliness in the region in terms of economic sustainability and generates employment with the return of tourism.

The use of some of the fixed furnishings as exhibition elements coincides with the understanding of sustainable protection. Thus, the stove, cabinet, and shelves as fixed furnishings and accessories continue to exist as functional elements and are concrete examples that reveal the life culture of the past. In terms of social sustainability, the architectural character, fixed and mobile furnishings, local materials, technics and workmanship and lifestyle reflect socio-cultural and family structure. In addition, Şevket Demirel is an important figure for the village. For this reason, the spiritual value of the museum house, where documents, photographs, furnishings and accessories belonging to Şevket Demirel are exhibited, is quite large. The use of local materials manifests itself, starting from the skeleton structure. While re-functioning; continuity has been achieved in terms of environmental sustainability principle with the use of new materials in accordance with the original texture in place of deformed materials.

\subsubsection{Demirel Museum House}

On the ground floor of Demirel Museum house; there are yerden ev, haney altı and porch; on the first floor; there is a main room, room and anteroom (Table 4). 
Table 4. Refuctioned Demirel Museum House [78].

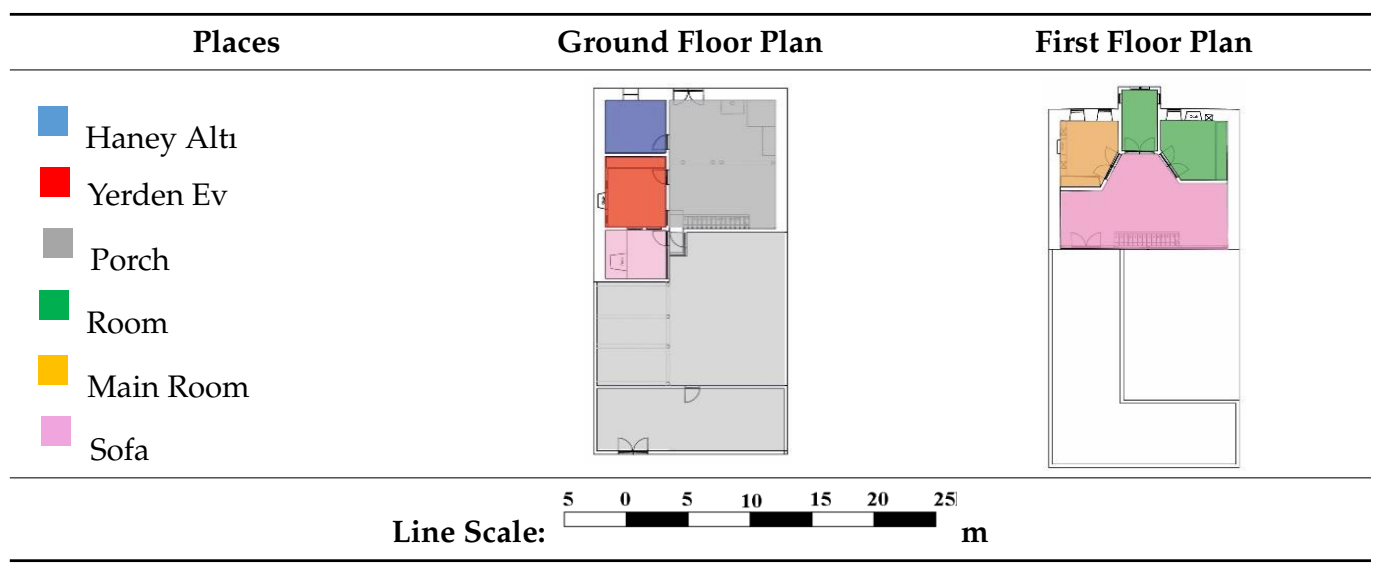

Yerden ev and porch areas have been functioned as museums. On the first floor, there are rooms called Haci Ali Demirel, Şevket Demirel and Süleyman Demirel. The house, which was the family home where the Demirel family was born and raised, was transformed into a museum house, while daily life was revived with objects and sculptures. The structure is one of the most important sources of liveliness in the region in terms of economic sustainability. Another importance of the museum is that it highlights the fact that a person born and raised in such a house can become president, emphasizing that Turkey is a democratic country. Therefore, it is very important in terms of social sustainability.

As in Şevket Demirel Museum House, the use of some of the fixed furnishings as exhibition elements coincides with the understanding of sustainable protection.

Fixed furnishings in the dwelling are the stove, cabinet and shelves. These equipments are produced with materials obtained from local sources, as in the Şevket Demirel Museum house; the structure manifests itself starting from the skeleton structure. Similarly, the continuity of the original texture is aimed where there is deformation caused by the construction by the same team in the complex.

4.2.3. Haci Ali Demirel House Is outside the Scope of the Museum and Is Used as a Private Property

On the ground floor of Hac1 Ali Demirel Museum House; there are yerden ev, porch; and on the first floor, there is a main room, room and an anteroom (Table 5).

Table 5. Refunctioned Haci Ali Demirel House [78].

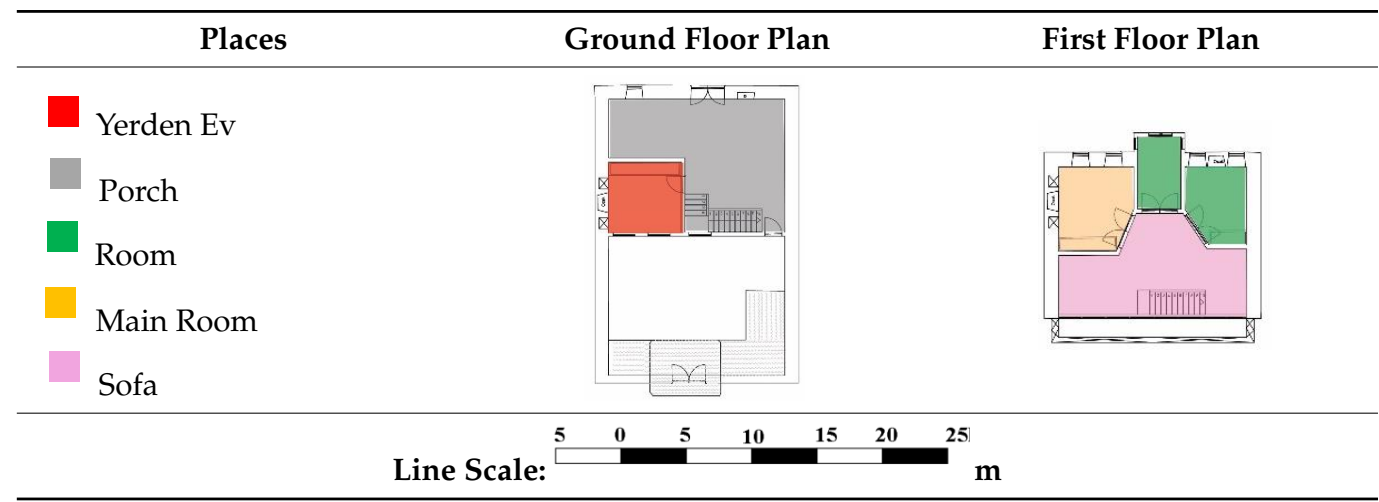

Yerden ev and porch have been functioned as museums. On the first floor, the main room, rooms and anteroom have been utilized in functions such as exhibit elements. The structure constitutes one of the sources of liveliness in terms of economic sustainability.

As in other museum houses in the complex, fixed furnishings in the dwelling are the stove, cabinet and shelves, and the use of some of the fixed furnishings as exhibition 
elements coincides with the understanding of sustainable protection. Thus, fixed reinforcement and accessories continue to exist as functional elements and are concrete examples that reveal the life culture in the past. Regarding social sustainability, the architectural character, fixed and mobile furnishings, local materials, technics and workmanship and lifestyle reflect socio-cultural and family structure. The use of local materials manifests itself starting from the structure skeleton. In the process of re-functioning, it can be said that environmental sustainability continues with new materials in accordance with the original texture as in other structures.

\subsubsection{Guesthouse}

On the ground floor of the guesthouse there is a yerden ev, a porch, a room and an anteroom (Table 6).

Table 6. Re-functioned guest house [78].

\begin{tabular}{lllll}
\hline \multicolumn{1}{c}{ Places } & Ground Floor Plan & First Floor Plan \\
\hline Yerden Ev & & \\
Porch & & \\
Room & & & \\
Sofa & Line Scale: & & \\
\hline
\end{tabular}

Yerden ev and porch areas have not yet been re-functioned. On the first floor, the rooms have been utilized as relaxation area and guest house, while the anteroom is utilized as a circulation area. When the building, which has been converted from residence to guesthouse, is completed, it will make an important contribution in terms of economic sustainability.

As for fixed furnishings, the stove in the anteroom and the shelves in the room have been refurbished, the furnishings such as cabinets and shelves have not been re-used. Ceramic flooring, which is used in the porch and yerden ev spaces stands out as contrary to local materials. This situation is inconvenient in terms of the continued environmental sustainability, and also damages the original texture. The furniture designed in the rooms on the first floor, the carpets selected for the flooring and especially the cabinet among the fixed furnishings do not match the local character, do not reflect the socio-cultural structure and cannot convey the life culture of the region. This sets the wrong example for future generations in terms of social sustainability.

\subsubsection{Lodging}

Traditional residence number 5 consists of two floors. On the ground floor of the traditional residence with the external anteroom plan type, there are porch, yerden ev and haney alt1; and on the first floor, there are two rooms and an anteroom (Table 7).

The refunctioned dwelling has been restored to allow use as lodgings. The function provided in the complex has met the needs and quality of life of the employees. Thus, it created employment aimed at improving the quality of life of the people of the region.

On the ground floor of the building, the porch area has been converted into a dining area for restaurant use; yerden ev to the kitchen space by removing the wall of the house area; and the haney altı section to wet areas. On the first floor of the building, the part where the stove is located in the anteroom area has been raised from the ground, and by dividing one area has been resolved as an open kitchen space and bathroom. Rooms have been planned and restored to provide accommodation. Social sustainability was ensured by little intervention and re-functioning of the structure as a lodging in terms of traditional 
use and originality. It can be said that local resources belonging to the region are used in terms of the use of stone and wood materials in the structure so that the texture does not deteriorate. In this sense, the texture of the existing structured environment continues. In addition, energy efficiency was obtained by providing energy to meet the needs in the use of housing in the structure in natural ways such as using solar energy.

Table 7. Re-functioned Lodging [78].

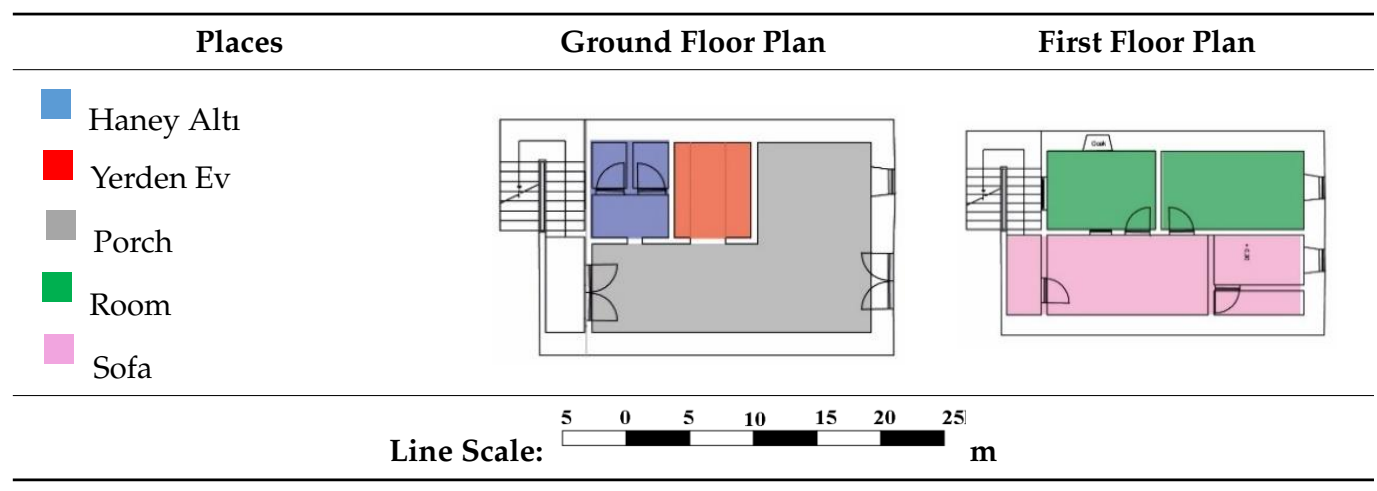

\subsubsection{Haci Abdil Ağa Masjid and Ağalar Kıraathanesi (Coffee House)}

Traditional residence number 6 consists of two floors. On the ground floor of the traditional residence belonging to the external anteroom plan type, there is a porch and a connected room; on the first floor; there is a room (Table 8).

Table 8. Re-functioned Haci Abdil Ağa Masjid and Ağalar Kıraathanesi (Coffee House) [78].

\begin{tabular}{llllll}
\hline & Places & Ground Floor Plan & & First Floor Plan \\
\hline Room & & & \\
Porch & & & \\
\hline & Line Scale: & & & \\
\hline
\end{tabular}

The village room was made to serve accommodation and gathering purposes; it has been re-functioned and converted into a country house and masjid. It can be said that social sustainability continues with this structure because it ensures that all users come together. The area planned as kiraathane is a term that used for gathering place. This area is stated on the building's ground floor and surrounded with an exhibition of paintings belonging to the region.

On the ground floor of the re-functioned structure the porch has been planned as a kiraathane and the upper floor as a masjid area. An open kitchen area was designed in the kiraathane area and up-to-date paintings were displayed on the walls. The architectural typology of the first floor is damaged; the existing two room walls were demolished and a combined anteroom and masjid area was designed. Therefore, the destruction of the original plan scheme has affected the continuity of both social and environmental sustainability. However, the original character of the façade has not been destroyed; the sustainability of the artificial environment was ensured with both construction technique and the use of local materials.

\subsubsection{Culture and Art House}

Traditional residence number 7 consists of one floor. It is believed that the traditional residence with an anteroom plan type consisted of two floors and living space on the ground floor and an anteroom and rooms on the upper floor before being restored (Table 9). 
Table 9. Re-functioned Culture and Art House [78].

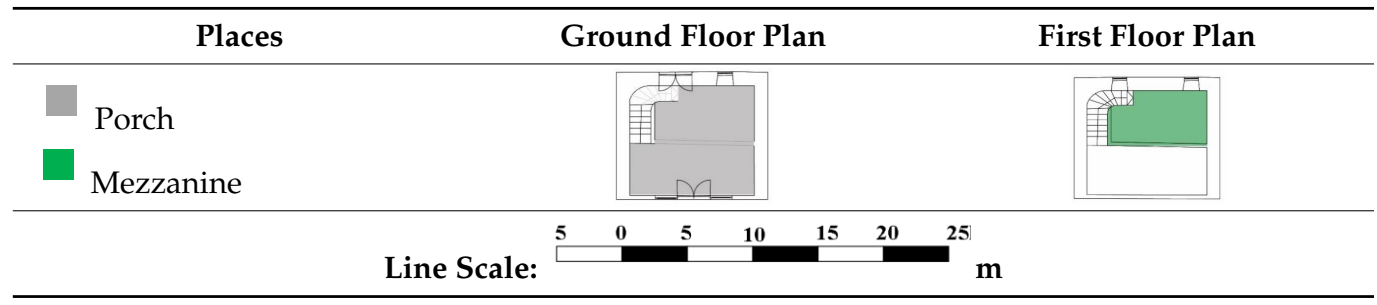

On the ground floor of the re-functioned building, the porch was divided with a mezzanine and was restored as a cultural art house where paintings gifted to Süleyman Demirel are being exhibited. The use of stones and mud bricks, which is the original use and construction technique of the structure, has been continued. The changes in original architectural plan of the building and in the building elements caused the character of the interior to deteriorate.

Within the scope of social sustainability, the spiritual value of the cultural art house where the photographs gifted to Süleyman Demirel are exhibited is quite big. In this respect, the cultural diversity and identity of the region have been preserved. The re-functioning of the building as a cultural and artistic house has provided tourism returns in terms of economic sustainability and provides job employment for local people while at the same time supporting social development with different activities.

\subsubsection{Demirel Foundation Presidency}

Traditional residence number 8 consists of two floors. On the ground floor of the traditional residence with the external anteroom plan type there are porch, haney alt1, two rooms and two pantry rooms; on the upper floor there is an anteroom, main room, two rooms and a terrace. (Table 10).

Table 10. Re-fuctioned Demirel Foundation Presidency [78].

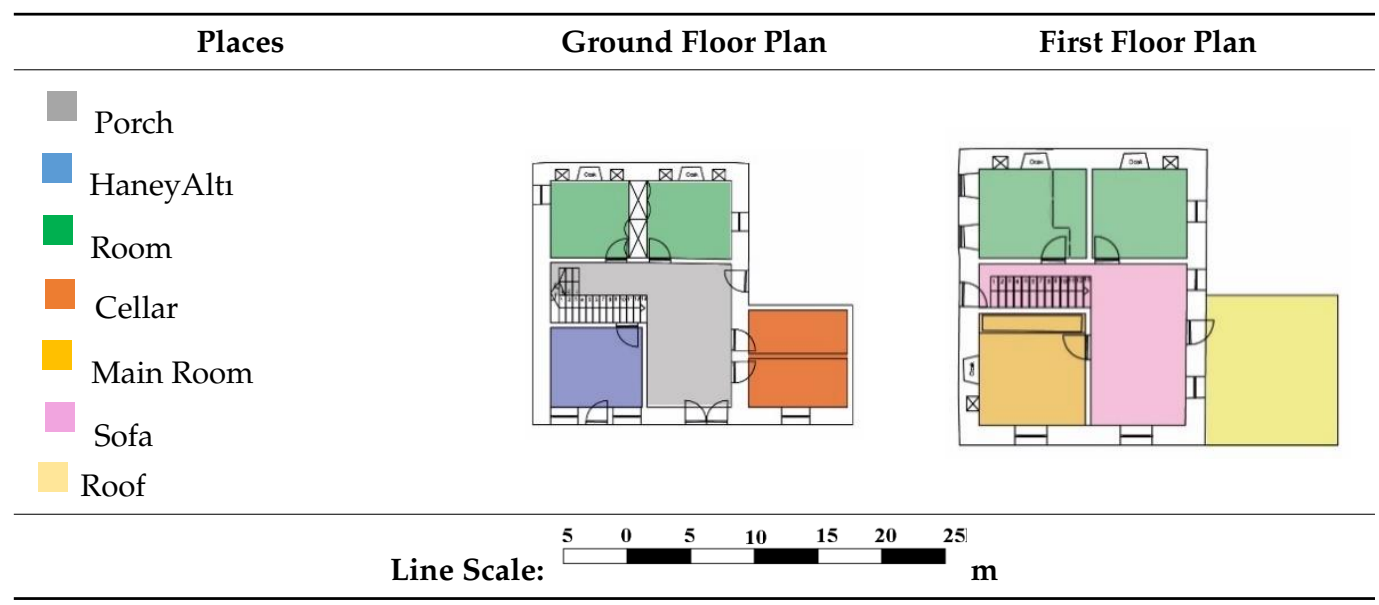

The structure has been re-functioned as a management structure belonging to the Demirel Foundation Presidency. On the ground floor, the haney altı section has been thought of as a book house, but no segregation arrangements have been made. The furnishings of the management building have not yet been completed, except for the meeting table located at the anteroom on the first floor. Local materials were preserved with the use of local stone and wood in the restoration of the building. In the same way, attention was paid to the use of local techniques and materials in the façade character.

The use of the dwelling as a management structure and its restoration with little intervention have reduced the costs of operation, maintenance and repair in terms of economic sustainability. Further design of the bookstore space located on the ground floor 
of the building has supported the social function of the complex and can also contribute to the local workforce of tourism.

\section{Results}

\subsection{Evaluation of Environmental Sustainability for Local Architecture Re-Functioned Demirel Complex}

Demirel Complex is a complex consisting of traditional houses surrounding the building island where Akın street and Hürriyet and Cumhuriyet streets are located, consisting of newly built buildings. The restoration process for the protection of nine traditional houses, which is an important local resource on the designated parcel, began with the purchase by Demirel Foundation. Most of the structures were in ruins and had subsidiary buildings built later in their garden. These spaces, which were added later for adaptive reuse, were removed from the gardens; it has been restored, taking into account the original plan schemes of the residences. In the process of rebuilding the structures, efforts were made to ensure the sustainability of the characteristic environmental feature created by the artificial environment by preserving the façade, architectural elements and morphological elements within the aesthetic and artistic values (Figure 9).

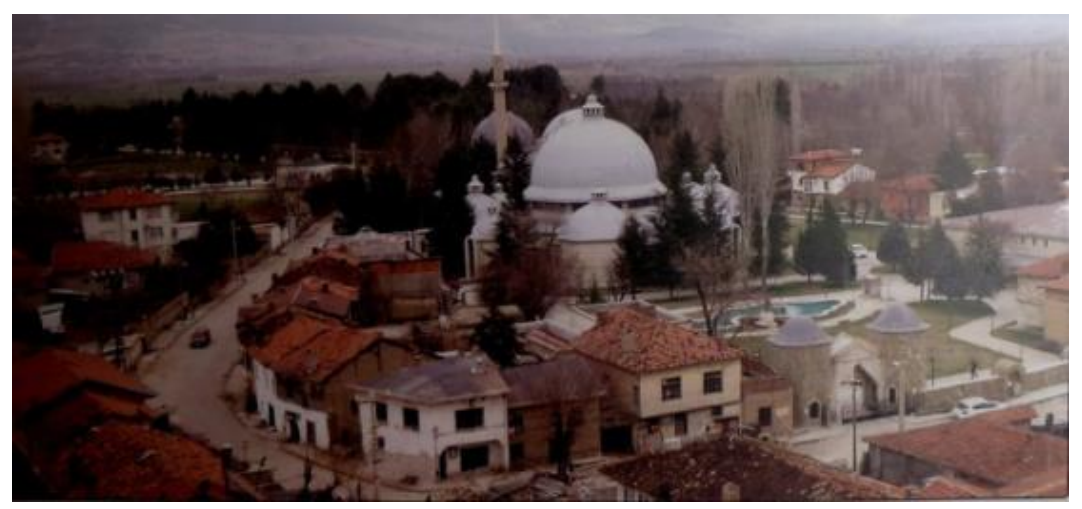

Figure 9. Süleyman Demirel Complex before restoration [79].

Apart from the aforementioned, another environmental sustainability principle is the efficient use of energy. Due to the construction of traditional houses before energy sources such as electricity, applications such as natural lighting and increasing insulation using carpets, etc. have made them consume as little energy as possible. In this respect, the refunctioning of the structures in the settlement enabled the sustainability of passive energy.

Another piece of environmental data other than traditional dwellings, which is an important element in terms of artificial environment is the redefining of the building island with landscape elements without damaging its natural texture in the village. Thus, a relationship was achieved between the newly built buildings and the old houses; the functional continuity of the parcel, which has become a complex function has been supported. Circulation routes for the group of people visiting the complex between old and new structures, ornamental pools and seating areas are set up (Figure 10a,b). 


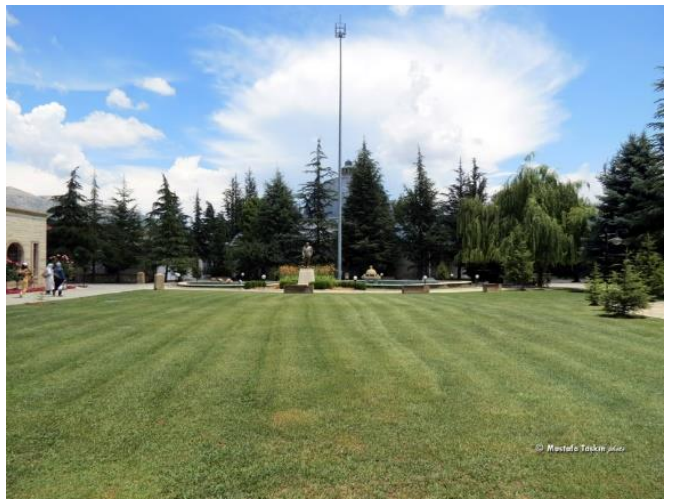

(a)

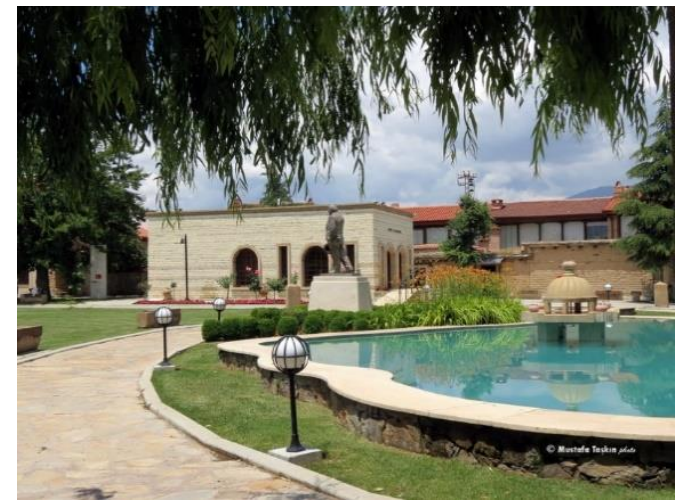

(b)

Figure 10. Süleyman Demirel Complex after restoration $(\mathbf{a}, \mathbf{b})[79]$.

Within the Demirel complex, qualified public spaces have been established where visitors and tourists visiting İslamköy, as well as the people of İslamköy, can spend quality time.

\subsection{Evaluation of Economic Sustainability for Local Architecture in the Re-Functioned Demirel Complex}

Before the Demirel Complex, which was started in 1990, the protection status of the structures in İslamköy and the awareness of the local people in this sense were very poor. However, during the construction process of the complex, both the environmental regulations on the building island and the regeneration stages of the traditional houses, many of which are in ruins, caused both the local people to become aware and for the Isparta provincial of İslamköy to become an alternative tourism corridor economically. Thus, increased tourism activity brought with itself benefits such as employment and supporting of the local economy.

In the process of construction, supplying both the materials used in traditional houses and the building masters from the region and its surroundings has contributed to the development of different business sectors for the region economically. Around the complex in recent years, the desire of the residents to restore their own dwellings has also ensured that this economic development is sustainable. Thus, instead of demolishing and rebuilding these structures, which will be caused by increasing energy use and cause economic damage to the implementer, the adapting of existing houses has prevented both this energy consumption and economic difficulties. With all this, the character, values and memories of the built environment of İslamköy were preserved. However, the inability to make the architectural identity created with the complex in a similar way, especially for economic reasons, can create problems for the general texture of the settlement.

Another element of Economic Sustainability for Local Architecture is tourism returns. In this respect, Demirel Complex has caused important events to take place for both Isparta and İslamköy. The mobility around the region has brought with it the development of options for employment, especially after 2014. Among the activities, the opening of museum houses and Süleyman Demirel Museum of Democracy and Development both seven days a week and during all holidays, and different activities can be shown. An average of 8000 people visit the museum per month in the summer period and 2000 during the winter period (Figure 11a,b). 


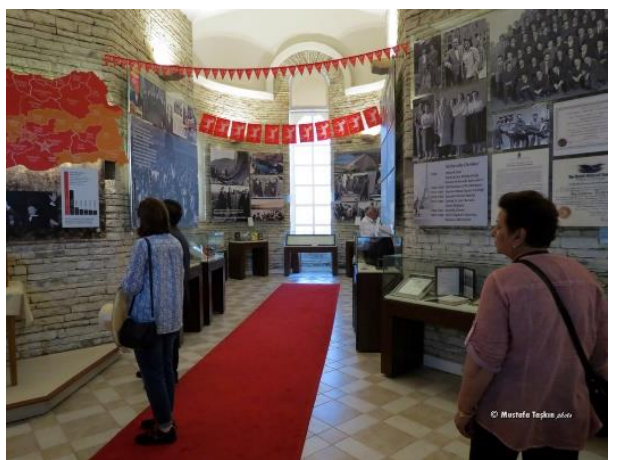

(a)

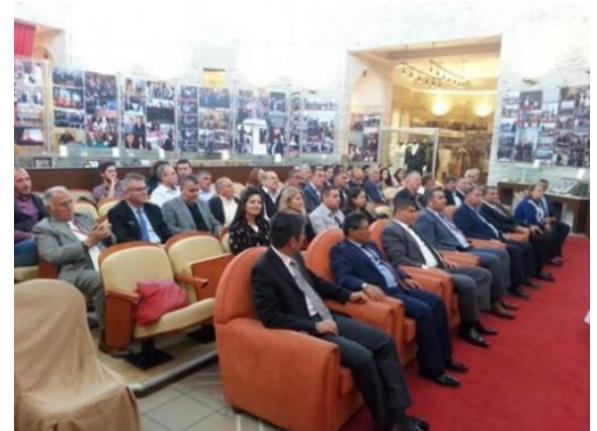

(b)

Figure 11. Süleyman Demirel Museum of Democracy and Development: (a) Showroom [79]. (b) Meeting room [80].

In addition, in accordance with a protocol signed by Süleyman Demirel University and the President of the Demirel Foundation, a building called "Süleyman Demirel Leadership Research and Application Center" has been allocated in the complex and has helped to create an academic environment. In this way, undergraduate, graduate and doctoral students in the complex were provided with the opportunity to conduct scientific research in the museum every week.

Another economic contribution is that İslamköy, which is among the tourism returns, is located within the routes of bicycle tours. These tours also brought many visitors to the village. Thus, it will be easier for the environmental features of the village to stand out.

With the active operation of the complex, the increase in the number of visitors in the settlement has caused both the diversification of cultural activities and the opening of food and beverage venues and outlets where local people promote their local food. In particular, the presence of different enterprises around the complex will contribute in the long term to the increase in the duration of stay of local visitors in the region and to the return of the young population who have migrated due to unemployment.

\subsection{Evaluation of Social Sustainability for Local Architecture in the Re-Functioned Demirel Complex}

The contribution of the complex to the settlement from a social point of view is that it was the village where President Süleyman Demirel who was particularly effective in Turkish politics and management after the Republican period was born and that the state mausoleum was considered an important value after his death. When the historical process of İslamköy is examined, it is seen that it has a rare potential in terms of its unique concrete and intangible cultural heritage values and local identity.

There are 46,000 books, 42,000 newspapers and magazines, 8000 gift items, 4000 paintings, 6000 tapes and videotapes, 126,000 photographs, 550 carpet-rugs and clothing 6 million documents, and a total of 6,300,000 materials [80] in the complex. It can also be said that a complex where such a diverse inventory is collected creates a new social identity by another vision to İslamköy.

The museum house, which is re-functioned as Demirel Museum House (Father's Quarry) from traditional residences in the complex, also introduces İslamköy's traditional culture of living with both furniture and photographs. In terms of emphasizing the importance of diversity by addressing the way of life, spirituality, family and socio-cultural structure, the complex has an important place in terms of conveying the culture of life (Figure 12a-c). 


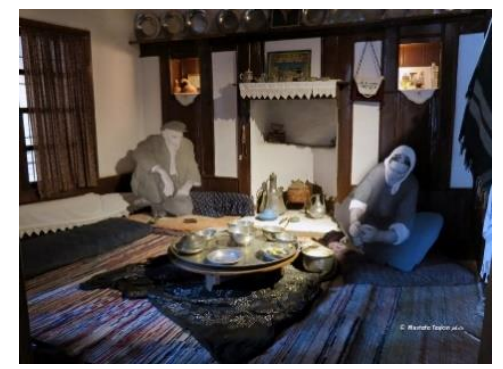

(a)

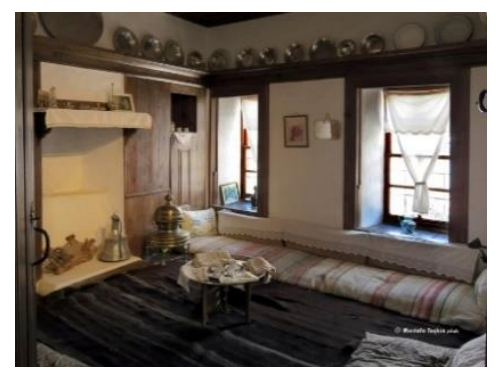

(b)

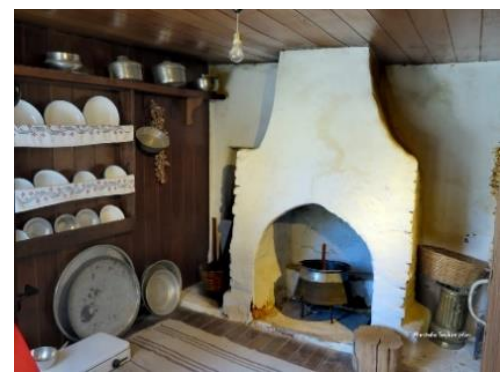

(c)

Figure 12. Demirel Museum House (a-c) [79].

Another indicator of social sustainability is the construction process of traditional houses around the complex. Especially after the purchase of these buildings for restoration purposes; houses with detached gardens were built on the land in the village for residents; thus, the residents of the village were ensured to stay in the settlement. In addition, the construction stages of these houses were exemplary in ensuring the continuity of local construction and culture. The implementation stages of different crafts such as mud brick production, woodworking, etc. in the construction process of the complex have ensured both the protection of the artisanal activities of local craftsmen and the awareness of the public by increasing their participation in the process.

\section{Conclusions}

The construction of new buildings and the re-functioning of traditional houses, which began with the construction of Demirel complex in İlamköy settlement, contributed to the revitalization of the settlement. However, with the construction of this building complex and the restoration works of traditional houses, it is seen that the purpose of construction is ensured. In the study, the contribution of the complex, which has become an important symbol for İslamköy, to environmental, economic and social sustainability after 2014 was discussed; in particular, we listed the advantages and disadvantages of the re-functioning process for İslamköy as follows (Table 11).

With the construction of the Demirel complex, the re-functioning of traditional houses and the functional contributions of newly built structures have revealed a sustainable approach that ensures public awareness while protecting local resources in İslamköy. While especially the development of environmental features together with the complex highlights the increase of tourism activities and economic sustainability, it has also brought about social developments. İslamköy is also an exemplary village for the republican regime and our democratic system. This is because he has shown that someone born in a rural settlement, in a mud brick house, can be the prime minister and president of the country thanks to this regime and system.

However, it is possible to collect what can be done and the measures to be taken for the continuity of the change that begins with the complex under the following headings:

Providing investment incentives in order to protect the environment and control the effectiveness of these incentives; 
Organizing training programs for the activities of tourism to raise awareness of local people, masters and enterprises in terms of developing local identity and thus increasing the importance to be given to the environment;

Ensuring that the public and visitors express their opinions on tourism, ensuring the continuity of local culture socially;

Design principles for refuted structures are carried out in accordance with the elements that are considered in the Demirel complex.

Table 11. Advantages and disadvantages that may be experienced after the use of Demirel Complex.

\begin{tabular}{ll}
\hline \multicolumn{1}{c}{ Advantages } \\
\hline $\begin{array}{l}\text { Increasing the tourism supply of the complex in İslamköy } \\
\text { enables the opening of different businesses such as food } \\
\text { businesses and sales places around it and improves competition. }\end{array}$ & $\begin{array}{l}\text { Except for the display of the local values of İslamköy in the } \\
\text { complex; introducing Süleyman Demirel, an important } \\
\text { politician for Turkey, gave the settlement a social identity. }\end{array}$ \\
\hline $\begin{array}{l}\text { Increasing the tourism supply of the complex in İslamköy } \\
\text { increases duration of stay of local visitors in the region and } \\
\text { contributes in the long term contributes to the return of the } \\
\text { young population who migrated due to unemployment. }\end{array}$ & $\begin{array}{l}\text { Non-governmental organization such as "Productive Women's } \\
\text { Association" was established; this has created production and } \\
\text { employment. }\end{array}$ \\
$\begin{array}{l}\text { Awareness is formed using local resources such as materials, } \\
\text { building masters, etc. in the immediate vicinity for }\end{array}$ & $\begin{array}{l}\text { The construction of the complex enables the continuity of } \\
\text { identity in terms of both natural and local architecture. }\end{array}$ \\
\hline $\begin{array}{l}\text { Traditional houses consume as little energy as possible due to } \\
\text { the period in which they are built. The re-functioning process } \\
\text { ensures the continuity of passive energy. }\end{array}$ & \begin{tabular}{l} 
The complex provides an important tourism return for İslamköy. \\
\hline $\begin{array}{l}\text { Due to the increase in tourism supply, decreases in the } \\
\text { purchasing power of local people occur. }\end{array}$
\end{tabular} \\
$\begin{array}{l}\text { Increased re-functioning in the complex; it has triggered similar } \\
\text { works in the local people's own residences in İslamköy. }\end{array}$ & $\begin{array}{l}\text { Increased re-functioning works in the process increase the } \\
\text { prices of energy and local resources. } \\
\text { of these practices. }\end{array}$ \\
\hline
\end{tabular}

Author Contributions: Ş.E.B.: Conceptualization, Collected data, Performed the analysis, Writing, S.K.A.: Collected data, Writing, A.D.: Methodology, Supervision, Validation, Writing-review and editing. M.A.: Contributed data and analysis tools, Writing. All authors have read and agreed to the published version of the manuscript.

Funding: This research received no external funding.

Institutional Review Board Statement: The study does not cover any conducted survey and any issue related to the Ethics Committee Report.

Informed Consent Statement: Not applicable for studies not involving humans.

Data Availability Statement: Data was obtained from Süleyman Demirel Museum of Democracy and Development with their kind permission and support.

Acknowledgments: We would like to express our thanks to Osman SİVILOĞLU, Director of Süleyman Demirel Museum of Democracy and Development for his valuable contributions during the process of preparing this article. We extend our thanks to the interior designer Tülin Tolun, who shared all his knowledge with us, to the Demirel Family, and to Atilla Gül for his contributions in the study.

Conflicts of Interest: The authors declare no conflict of interest. 


\section{References}

1. Çetin, S. Geleneksel Konut Mimarisinin Ekolojik Yansımaları: Burdur Örneği. 5. Ulusal Çatı Cephe Sempozyumu. 2010. Available online: http:/ / catider.org.tr/pdf/sempozyum5/Semp\%205\%20Bildiri\%2015.pdf (accessed on 16 February 2021).

2. Scott, M.M.; Frew, A.J. Exploring the role of in-trip applications for sustainable tourism: Expert perspectives. In Information and Communication Technologies in Tourism; Springer: Berlin/Heidelberg, Germany, 2013; pp. 36-46.

3. Report of the World Commission on Environment and Development. Available online: http://www.un.org/documents/ga/res/ 42/ares42-187.htm (accessed on 20 October 2008).

4. Yavuz, A. Sürdürülebilirlik Kavramı Ve İşletmeler Açısından Sürdürülebilir Üretim Stratejileri. J. Soc. Sci. Inst. 2010, 7, 63-86.

5. What Is Sustainable Development? Available online: http://www.menominee.edu/sdi/whatis.htm (accessed on 2 October 2008).

6. Kim, J.J.; Rigdon, B. Sustainable Architecture Module: Introduction to Sustainable Design; National Pollution Prevention Center for Higher Education: Cambridge, UK, 1998.

7. Kohler, N. The relevance of green building challenge: An observer's perspective. Build. Res. Inf. 1999, 27, 309-320. [CrossRef]

8. Williams, D.E. Sustainable Design: Ecology, Architecture, and Planning; Wiley: Hoboken, NJ, USA, 2007; Volume 7, pp. 37-44, 81-104.

9. Murzyn-Kupisz, M. Cultural, economic and social sustainability of heritage tourism: Issues and challenges. Econ. Environ. Stud. 2012, 12, 113-133.

10. Arpacıŏ̆lu, Ü. Kırsal Sürdürülebilirlikte Yeni Bir Model: Köyünü Yaşat Projesi. Yapı Derg. 2016, 421, $132-138$.

11. Ball, R. Developers, regeneration and sustainability issues in the reuse of vacant buildings. Build. Res. Inf. 1999, $27,140-148$. [CrossRef]

12. Wilkinson, S.; Reed, R. The business case for incorporating sustainability in office buildings: The adaptive reuse of existing buildings. In Proceedings of the 14th Annual Pacific Rim Real Estate Society Conference, Pacific Rim Real Estate Society, Kuala Lumpur, Malaysia, 20-23 January 2008.

13. Bullen, P.A.; Love, P.E.D. Residential regeneration and adaptive reuse: Learning from the experiences of Los Angeles. Struct. Surv. 2009, 27, 351-360. [CrossRef]

14. Philokyprou, M.; Michael, A.; Malaktou, E.; Savvides, A. Environmentally responsive design in Eastern Mediterranean. The case of vernacular architecture in the coastal, lowland and mountainous regions of Cyprus. Build. Environ. 2016, 111, 91-109. [CrossRef]

15. Schittich, C. In Detail, Solar Architecture, Strategies, Visions, Concepts; Kösel GmbH \& Co. KG: Kempten, Germany, 2003.

16. Başakman, M. Bir Araştırma Projesi: Geleneksel—Bölgesel Mimarinin Yorumlanması. Yapı Derg. 1993, 135, 59-70.

17. Özgünler, M. Kırsal Sürdürülebilirlik Bağlamında Geleneksel Köy Evlerinde Kullanılan Toprak Esaslı Yapı Malzemelerinin İncelenmesi. Mimarlık Bilimleri ve Uygulamalar Dergisi (MBUD) 2017, 2, 33-41. [CrossRef]

18. Correia, M.; Dipasquale, L.; Mecca, S. VERSUS: Heritage for Tomorrow; Firenze University Press: Firenze, Italy, 2014.

19. Ruda, G. Rural Building and Environment. Landsc. Urban Plan. 1998, 41, 93-97. [CrossRef]

20. Kısa Ovalı, P.; Delibaş, N. Yerel mimarinin sürdürülebilirliği kapsamında Kayaköy'ün çözümlemesi. MEGARON Yıldız Teknik Üniversitesi Mimarlık Fakültesi E-Dergisi 2016, 11, 515-529.

21. Kuban, D. Tarihi Çevre Korumanın Mimarlık Boyutu Kuram ve Uygulama; Yapı Endüstri Merkezi Yayınları: İstanbul, Türkiye, 2000; p. 207.

22. Stival, C.A.; Berto, R.; Morano, P.; Rosato, P. Reuse of Vernacular Architecture in Minor Alpine Settlements: A Multi-Attribute Model for Sustainability Appraisal. Sustainability 2020, 12, 6562. [CrossRef]

23. Mazzarella, L. Tarihi ve mevcut binaların enerji iyileştirmesi. Yasal ve düzenleyici bakış açısı. Enerji ve Binalar 2015, 95, 23-31.

24. Latham, D. Creative Reuse of Buildings; Donhead Publishing: Shaftesbury, UK, 2000.

25. Wilkinson, S.; Reed, R.; Kimberley, J. Using building adaptive reuse to deliver sustainability in Australia. Struct. Surv. 2009, 27, 46-61. [CrossRef]

26. Department of Environment and Heritage (DEH). Adaptive Reuse; Department of Environment and Heritage (DEH): Canberra, Australia, 2004.

27. Bromley, R.D.F.; Tallon, A.R.; Thomas, C.J. City centre regeneration through residential development: Contributing to sustainability. Urban Stud. 2005, 42, 2407-2429. [CrossRef]

28. Cooper, I. Post-occupancy evaluation-where are you? Build. Res. Inf. 2001, 29, 158-163. [CrossRef]

29. Bullen, P.; Love, P. The rhetoric of adaptive reuse or reality of demolition: Views from the field. Cities 2010, 27, 215-224. [CrossRef]

30. Gezer, H. Geleneksel Safranbolu Evlerinin Sürdürülebilirlik Açısından Değerlendirilmesi. İstanbul Ticaret Üniversitesi Fen Bilimleri Dergisi 2013, 12, 13-31.

31. Fernandes, J.; Mateus, R.; Bragança, L.; Correia da Silva, J.J. Portuguese vernacular architecture: The contribution of vernacular materials and design approaches for sustainable construction. Archit. Sci. Rev. 2015, 58, 324-336. [CrossRef]

32. Bullen, P.; Love, P. Adaptive reuse of heritage buildings. Struct. Surv. 2011, 29, 411-421. [CrossRef]

33. Lazrak, F.; Nijkamp, P.; Rietveld, P.; Rouwendal, J. Cultural heritage and creative cities: An economic evaluation perspective. In Sustainable City and Creativity: Promoting Creative Urban Initiatives; Girard, P., Baycan, L.F., Nijkamp, T., Eds.; Ashgate Publishing: Farnham, UK, 2012; pp. 225-243.

34. Celadyn, M. Interior Architectural Design for Adaptive Reuse in Application of Environmental Sustainability Principles. Sustainability 2019, 11, 3820. [CrossRef] 
35. Yoon, J.; Park, J. Comparative analysis of material criteria in neighborhood sustainability assessment toolsand urban design guidelines: Cases of the UK, the US, Japan, and Korea. Sustainability 2015, 7, 14450-14487. [CrossRef]

36. Powter, A.; Ross, S. Integrating environmental and cultural sustainability for heritage properties. APT Bull. 2005, 36, 5-11.

37. Han, J.; Kim, S. Heritage value through regeneration strategy in Mapo Cultural Oil Depot, Seoul. Sustainability 2018, 10 , 3340. [CrossRef]

38. International Charter for the Conservation And Restoration Of Monuments And Sites. Available online: http://www.icomos.org. tr/Dosyalar/ICOMOSTR_tr0605742001542305046 (accessed on 20 November 2020).

39. Langston, C.; Yung, E.H.K.; Chan, E.H.W. The application of ARP modelling to adaptive reuse projects in Hong Kong. Habitat Int. 2013, 40, 233-243. [CrossRef]

40. Pendlebury, J. Conservation and regeneration: Complementary or conflicting processes? The case of Grainger Town, Newcastle upon Tyne. Plan. Pract. Res. 2002, 17, 145-158. [CrossRef]

41. Strange, I.; Whitney, D. The changing roles and purposes of heritage conservation in the UK. Plan. Pract. Res. 2003, 18, 219-229. [CrossRef]

42. Goodland, R.; Daly, H. Environmental sustainability: Universal and non-negotiable. Ecol. Appl. 1996, 6, 1002-1017. [CrossRef]

43. Salman, M. Sustainability and Vernacular Architecture: Rethinking What Identity Is; Intechopen: London, UK, 2018. [CrossRef]

44. Yarrow, T. Building on the Past: Exploring the intersections between energy, environment and authenticity through an ethnographic study of renovation. In Proceedings of the 2nd International Conference on Preservation, Maintenance and Rehabilitation of Historic Buildings and Structures, Porto, Portugal, 22-24 July 2015; pp. 615-623.

45. Tu, H.M. The Attractiveness of Adaptive Heritage Reuse: A Theoretical Framework. Sustainability 2020, 12, 2372. [CrossRef]

46. Konstantinou, T.; Dimitrijević, B. Sustainable refurbishment for an adaptable built environment. In Sustainable and Resilient Buildings: Approaches, Methods and Tools; Kosanović, S., Klein, T., Konstantinou, T., Radivojević, A., Hildebrand, L., Eds.; TU Delft: Delft, The Netherlands, 2018; pp. 207-227.

47. Koca, G. Evaluation of Traditional Şirince Houses According to Sustainable Construction Principles. Int. J. Archit. Plan. 2019. [CrossRef]

48. Kohler, N.; Yang, W. Long-termmanagementofbuilding stocks. Build. Res. Inf. 2007, 35, 351-362. [CrossRef]

49. Johnson, A. Rehabilitation and re-use of existing buildings. In Building Maintenance and Preservation: A Guide to Design and Management; Mills, E.D., Ed.; Architectural Press: Oxford, UK, 1996; pp. 209-230.

50. Ellison, L.; Sayce, S.; Smith, J. Socially responsible property investment: Quantifying the relationship between sustainability and investment property worth. J. Prop. Res. 2007, 24, 191-219. [CrossRef]

51. Sev, A. Sürdürülebilir Mimarlı; Yapı Endüstri Merkezi Yayınları: İstanbul, Turkey, 2009.

52. Merlín-Uribe, Y.; González-Esquivel, C.E.; Contreras-Hernández, A.; Zambrano, L.; Moreno-Casasola, P.; Astier, M. Environmental and socio-economic sustainability of chinampas (raised beds) in Xochimilco, Mexico City. Int. J. Agric. Sustain. 2013, 11, 216-233. [CrossRef]

53. Philokyprou, M.; Michael, A. Environmental Sustainability in the Conservation of Vernacular Architecture. The Case of Rural and Urban Traditional Settlements in Cyprus. Int. J. Archit. Herit. 2020. [CrossRef]

54. Matero, F.G. Loss, compensation and authenticity: The contribution of Cesare Brandi to architectural conservation in America. Future Anterier 2007, IV, 45-57.

55. Watson, G.; Bentley, I. Identity by Design; Elsevier Ltd.: Oxford, UK, 2007.

56. Pedersen, A. Managing Tourism at World Heritage Sites: A Practical Manual for World Heritage Site Managers; UNESCO World Heritage Centre: Paris, France, 2002.

57. The Scottish Office. Down to Earth: A Scottish Perspective on Sustainable Development; Scottish Office: Edinburgh, UK, 1999 ; p. 26. ISBN 0-7480-7171-7.

58. Koçhan, A. Doğal Çevreyle Kurulan Anlamsal Bağ: Sürdürülebilir Toplu Konut Tasarımı. Yapı Dergisi 2003, 256, 49-55.

59. Elinc, Z.; Kaya, L.; Elinç, H. Portable garden complex in protected urban areas. Int. J. Curr. Res. 2018, 10, 71095-71097. [CrossRef]

60. Kiper, P. Küreselleşme Sürecinde Kentlerin Tarihsel-Kültürel Değerlerinin Korunmas1-Türkiye-Bodrum Örneği, Doktora Tezi, Ankara. 2004. Available online: https:/ /dspace.ankara.edu.tr/xmlui/bitstream/handle/20.500.12575/28280/2289.pdf? sequence $=1 \&$ is Allowed $=y$ (accessed on 16 February 2021).

61. Selim, C.; Mutlu, S.S.; Selim, S. Kentsel Alanlarda Biyolojik Çeşitliliğin Sürdürülebilirliği Ve Koruma Yaklaşımları. Turk. J. Sci. Rev. 2015, 8, 18-45.

62. Almhafdy, A.; Ibrahim, N.; Ahmad, S.S.; Yahya, J. Thermal performance analysis of courtyards in a hot humid climate using computational fluid dynamics CFD method. Procedia Soc. Behav. Sci. 2015, 170, 474-483. [CrossRef]

63. Du, X.; Bokel, R.; Van den Dobbelsteen, A. Building microclimate and summer thermal comfort in free-running buildings with diverse spaces: A Chinese vernacular house case. Build. Environ. 2014, 82, 215-227. [CrossRef]

64. Ghaffarianhoseini, A.; Berardi, U.; Ghaffarianhoseini, A. Thermal performance characteristics of unshaded courtyards in hot and humid climates. Build. Environ. 2015, 87, 154-168. [CrossRef]

65. Van Geenhuisan, M.; Nijkamp, P. Sürdürülebilir Kenti Nasıl Planlamalı? Toplum ve Bilim Dergisi 1994, 64, 131.

66. Fulya, G.; Cansu, G.; Ahmet, K. Sürdürülebilir Kalkınma İçin Ekolojik Yapı Tasarım Kriterleri. Akad. Disiplinlerarası Bilimsel Araştırmalar Derg. 2017, 3, 92-107. 
67. Ozan, B. Sürdürülebilirlik Kavrami Ve Mimarlikta Tasarima Yansimasi. Master's Thesis, İstanbul Teknik Üniversitesi, İstanbul, Turkey, 2003.

68. El Sorady, D.A.; Rizk, S.M. LEED v4.1 mevcut binalar için operasyonlar ve bakım ve uygunluk değerlendirmesi: Bayt Al-Suhaymi, Tarihi Kahire. Alex. Eng. J. 2020, 59, 519-531.

69. Ertaş, S..; Sönmez, E.; Torun, A.; Kulak, F. The Awareness of Locals in Culture Tourism: The Sample of Sille/Konya. J. Sustain. Dev. 2017, 10, 125-134. [CrossRef]

70. Burcu, O.; Panayiotis, T.; Eyup, D. Re-estimating the interconnectedness between the demandof energy consumption, income, and sustainability indices. Environ. Sci. Pollut. Res. 2019, 26, 26500-26516.

71. Gillian, F.; Halliki, K. A review of environmental impact indicators of cultural heritage buildings: A circular economy perspective. Environ. Res. Lett. 2020, 15, 043003.

72. Feilden, B.M. Conservation of Historic Buildings; Elsevier: Amsterdam, The Netherlands, 2003.

73. Birol Akkurt, H. Reconstitution of the Place Identity within the Intervention Efforts in the Historic Built Environment. In the Role of Place Identity in the Perception, Understanding, and Design of Built Environments, 2nd ed.; Casakin, H., Bernardo, F., Eds.; Bentham Science Publishers: Sharjah, United Arab Emirates, 2012; pp. 63-77.

74. Wang, H.; Zeng, Z. A multi-objective decision-making process for reuse selection of historic buildings. Expert Syst. Appl. 2010, 37, 1241-1249. [CrossRef]

75. Üstün, R. İslamköy Tarihi; 1. Baskı; Yeni Matbaa: Isparta, Turkey, 2016; ISBN 978-605-030-174-8.

76. Isparta İl Kültür ve Turizm Müdürlüğü. Available online: https://isparta.ktb.gov.tr/TR-162906/suleyman-demirel-demokrasive-kalkinma-muzesi.html (accessed on 20 November 2020).

77. Koç, S. Geleneksel Konutların İç Mekan Kurgusunu Yerel Kimlik Unsurlarıyla Okumak: İslamköy Örneği. Yüksek LisansKaradeniz Teknik Üniversitesi: Türkiye, 2019. Available online: https:/ / tez.yok.gov.tr/UlusalTezMerkezi/tezDetay.jsp?id=haBs1 5GJUVFI1tEJ1J5UqQ\&no=uqDr6ma1BYiEzo2bOFL7uw (accessed on 16 February 2021).

78. Personal Archieve. Available online: http://mustafataskin.weebly.com/uploads/1/6/1/0/16108940/mg-8048-mt.jpg (accessed on 20 November 2020).

79. Süleyman Demirel Demokrasi ve Kalkınma Müzesi. Available online: https:/ /isparta.ktb.gov.tr/TR-162906/suleyman-demireldemokrasi-ve-kalkinma-muzesi.html (accessed on 20 November 2020).

80. İslamköy Tarihi. Available online: www.demirelvakfi.org (accessed on 1 February 2020). 